\title{
PATHOPHYSIOLOGY OF ENTEROAGGREGATIVE Escherichia coli INFECTION: an experimental model utilizing transmission electron microscopy
}

\author{
Jacy Alves Braga de ANDRADE¹, Edna FREYMÜLLER² and Ulysses FAGUNDES-NETO
}

\begin{abstract}
Context - Enteroaggregative Escherichia coli strains have been associated with persistent diarrhea in several developing countries. In vivo procedures with animal models as rat, rabbit and gnotobiotic piglets intestinal loops, in vitro assays with cellular lines like T84, Caco 2, HT29, HeLa e HEp-2 and in vitro organ culture with intestinal fragments have been applied to study these bacteria and their pathogenicity. Objectives - The present experimental research assessed the pathogenic interactions of three enteroaggregative Escherichia coli strains, using the in vitro organ culture, in order to observe and compare alterations in different regions of both, the ileal and the colonic mucosa. Methods - This study applied intestinal fragments from terminal ileum and colon that were excised from pediatric and adult patients that underwent colonoscopic procedures. Tissue was fixed for transmission electron microscopic study. Each bacterium was tested with three intestinal fragments for each region. Results - Enteroaggregative Escherichia coli strains colonized and provoked citotoxic effects in the ileal and colonic mucosa. Total or partial villi destruction, vacuolization of basal cytoplasm of the enterocytes, epithelium detachment, derangement of the structure and epithelial cell extrusion in ileal mucosa could explain the perpetuation of the diarrhea. Bacterial aggregates were seen in intestinal lumen associated with mucus and cellular debris and in the intercellular spaces of the destroyed epithelium, suggesting bacterial invasion that seemed to be secondary to the destruction of the tissue. Conclusions - Pathogenesis of persistent diarrhea should include alterations in the small bowel structures where the digestive-absorptive functions take place. In the colonic mucosa the inflammatory lesions could explain the occurrence of colitis.

HEADINGS - Escherichia coli. Diarrhea. Microscopy, electron, transmission.
\end{abstract}

\section{INTRODUCTION}

Diarrhea caused an estimated $13.2 \%$ of children deaths worldwide, in $2002^{(30)}$. The great majority of the diarrhea episodes in the human host resolve within the first week, however in children under the age of 5, 3\% to $19 \%$ have a persistent evolution lasting more than 2 weeks ${ }^{(29)}$. Persistent diarrhea has high impact on infantile morbidity and mortality rates in developing countries and more than $50 \%$ of the deaths due to diarrhea are associated to persistent episodes ${ }^{(30)}$. Persistent diarrhea continues to pose enormous challenges globally. It is critical to learn more about this disorder, most particularly how best to define, diagnose, triage and implement interventions. Research into epidemiology, host response and etiology should be performed in parallel ${ }^{(7)}$.

Epidemiological studies have demonstrated that enteroaggregative Escherichia coli (EAEC) are frequently associated with persistent diarrhea in developing countries $(4,10,19,36$. In Brazil, recent studies showed EAEC as an important agent of acute diarrhea in children under 5 years old $^{(2,37)}$. In the USA, EAEC is one of the most common bacterial pathogens identified in cases of diarrhea not associated with immunodeficiency or foreign travel ${ }^{(18)}$. It is known that alterations in the small bowel justify the extension of the diarrheiogenic process ${ }^{(6,16)}$. Persistent diarrhea is often manifested by a chronic enteropathy, with impaired mucosal healing and diminished digestive and absorptive capacity $(6,8,16)$. The causes of persistent diarrhea in populations are multifactorial such as bacterial overgrowth $^{(25)}$, malnutrition ${ }^{(9)}$, direct action of some enteropathogenic agents on the enterocyte, cow milk and/ or food intolerance as well as prior antibiotic therapy ${ }^{(16,20,}$ 29). Pathogens detected in persistent diarrhea are often not the same as those detected in the original acute episode, suggesting that secondary infections may be an important factor as a cause of the protraction of the diarrhea ${ }^{(3)}$.

After epidemiological evidences of the association between EAEC infection and diarrhea ${ }^{(35)}$, efforts have been made to explain the interaction of these agents with the intestinal mucosa.

Some Escherichia coli serotypes presenting diverse adherence properties in tissue culture assays have been reported as important enteropathogens. One of these

${ }^{1}$ Division of Pediatric Gastroenterology; ${ }^{2}$ Center of Electron Microscopy, Escola Paulista de Medicina, Universidade Federal de São Paulo, São Paulo, SP, Brasil.

Correspondence: Prof. Ulysses Fagundes Neto - Av. Cons. Rodrigues Alves, 1239 - Vila Mariana - 04014-012 - São Paulo, SP, Brasil. E-mail: ufagundesneto@uol.com.br 
types of enteropathogenic properties called enteroaggregative is characterized by the ability of some Escherichia coli strains (EAEC) to produce an aggregative pattern of adherence (AA) in cultured HEp-2 cell monolayers ${ }^{(32)}$. AA is identified by the presence of prominent bacterial auto agglutination on the cells' surfaces as well as on the glass coverslip free from cells. The main characteristic of AA, however, is the layering of bacteria, best described as a stacked-brick configuration.

The pathogenesis of EAEC is complex and EAEC strains are very heterogeneous ${ }^{(14)}$. Numerous putative virulence factors have been identified, but the clinical implication of these factors remain unclear ${ }^{(31)}$. More investigations on the interactions of EAEC with the intestinal mucosa are desirable.

The present study was designed to investigate three EAEC strains, isolated from infants with persistent diarrhea, interacting with ileal and colonic mucosa utilizing the transmission electron microscopy (TEM).

\section{METHODS}

\section{Bacterial strains and culture conditions}

EAEC strains: 171-1(ONT: H1), 101-1(ONT: H1) and 71-1(ONT: H33), previously isolated from stool specimens of hospitalized infants with persistent diarrhea in São Paulo, Brazil, were selected for this study. These strains were characterized as EAEC based on the production of the AA pattern in HEp-2 cells adhesion assay ${ }^{(32)}$ and EAEC probe hybridization $^{(5)}$. As positive controls, the Prototype strains 042 (O44:H18) ${ }^{(33)}$ infected fragments were used.

As negative controls, non-infected intestinal fragments were used.

Strains stored at room temperature in nutrient agar were routinely grown on triptych soy broth, in a period of 18 hours at $37^{\circ} \mathrm{C}$.

\section{In vitro organ culture adhesion assay}

Intestinal mucosa was obtained from terminal ileum and colon excised from pediatric patients in ileal and colonic surgeries or from ileal and colonic biopsies obtained from adult patients that underwent colonoscopies. In both cases, macroscopically normal tissues were selected. The fragments were collected from 18 colonoscopies, 4 colonic surgeries and 2 ileal surgeries. For each strain ( 3 wild strains and the prototype) we did 3 individual experiments in each site.

The adhesion assays were performed as described by Knutton et al. ${ }^{(28)}$, with some modifications. Biopsies were transported to the laboratory, after being placed in modified organ culture medium (MOCM) adapted from that described by Embaye et al. ${ }^{(15)}$ consisting of NCTC-135 (SIGMA) with $2 \mathrm{mM}$ of L-glutamin (SIGMA), MTT8 (FLOW) and new born calf serum. Some fragments were immediately fixed to microscopic evaluation (uncultured controls). Fragments were fixed in paraformaldehyde to be analyzed by TEM. EAEC strains were tested with three intestinal fragments of each intestinal region. Three biopsy samples were placed with their villi up on sterile filters (AP 20; Millipore) in a plastic Petri dish (35 x 10 mm;
Corning). The level of MOCM containing 1.0\% D-mannose was adjusted to cover the biopsy specimens with a thin film of medium by capillary action. For adhesion studies, $60 \mathrm{~mL}$ of a bacterial broth culture (overnight cultures at $37^{\circ} \mathrm{C}$ ) was added. Specimens incubated with tissue culture medium alone without the addition of bacteria were used as negative controls.

Petri dishes were then incubated at $37^{\circ} \mathrm{C}$ in a $95 \% \mathrm{O} 2-5 \%$ $\mathrm{CO} 2$ atmosphere, for 2 hours. Then, biopsy samples were washed 4 times with sterile phosphate buffered saline and incubated with $2 \mathrm{~mL}$ of MOCM containing 1.0\% D-mannose for additional 2, 4 and 6 hours at $37^{\circ} \mathrm{C}$. The culture medium was changed completely every 2 hours to maintain $\mathrm{pH}$ and nutrient levels, without reinoculation with bacterial culture. After these incubation periods, biopsy samples were washed and prepared for TEM.

\section{Tissue processing}

Biopsies were fixed in $\mathrm{mK}$, posfixed in $1 \%$ osmium tetroxide, and after complete sequential dehydration they were embedded in Araldite resin and maintained for 3 days at $60^{\circ} \mathrm{C}$ to polymerize. Ultra-thin sections were electronically stained with uranyl acetate and lead citrate, and analyzed by TEM (model 1200 EX-II, JEOL), operated at $80 \mathrm{kV}$.

\section{Ethical considerations}

This study protocol was approved by the Universidade Federal de São Paulo - Escola Paulista de Medicina, São Paulo, SP, Brazil - UNIFESP-EPM Ethical Commitee for Human Experimentation. Informed written consent was obtained from adults and parents of each participating infant.

\section{RESULTS}

\section{Adhesion to ileal fragments}

Analysis by TEM of infected fragments showed alterations that comprised microvilli destruction, epithelium detachment and totally destroyed areas. Bacterial aggregates were seen directly over the disaggregated surface of the tissue (Figure 1).

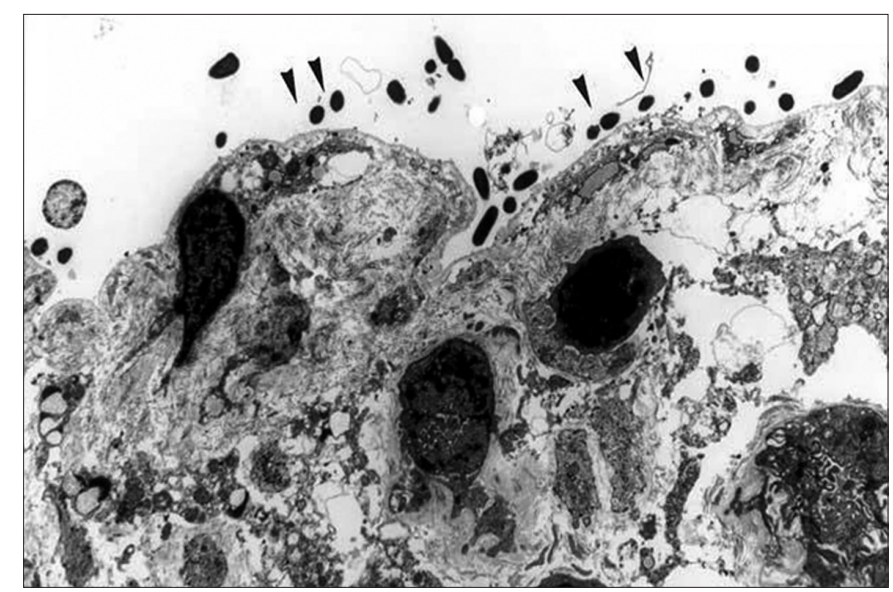

FIGURE 1. Ileal fragment infected by 171-1 EAEC strain showing epithelial surface destruction and adhesion of bacteria over the enterocytes ( 1 ) (transmission electron microscopy: 3250x) 
Analysis by TEM of the positive control showed alterations that comprised areas of microvilli destruction, epithelium detachment, microvilli vesiculation and vacuolization of the basal cytoplasm of the enterocytes (Figure 2).

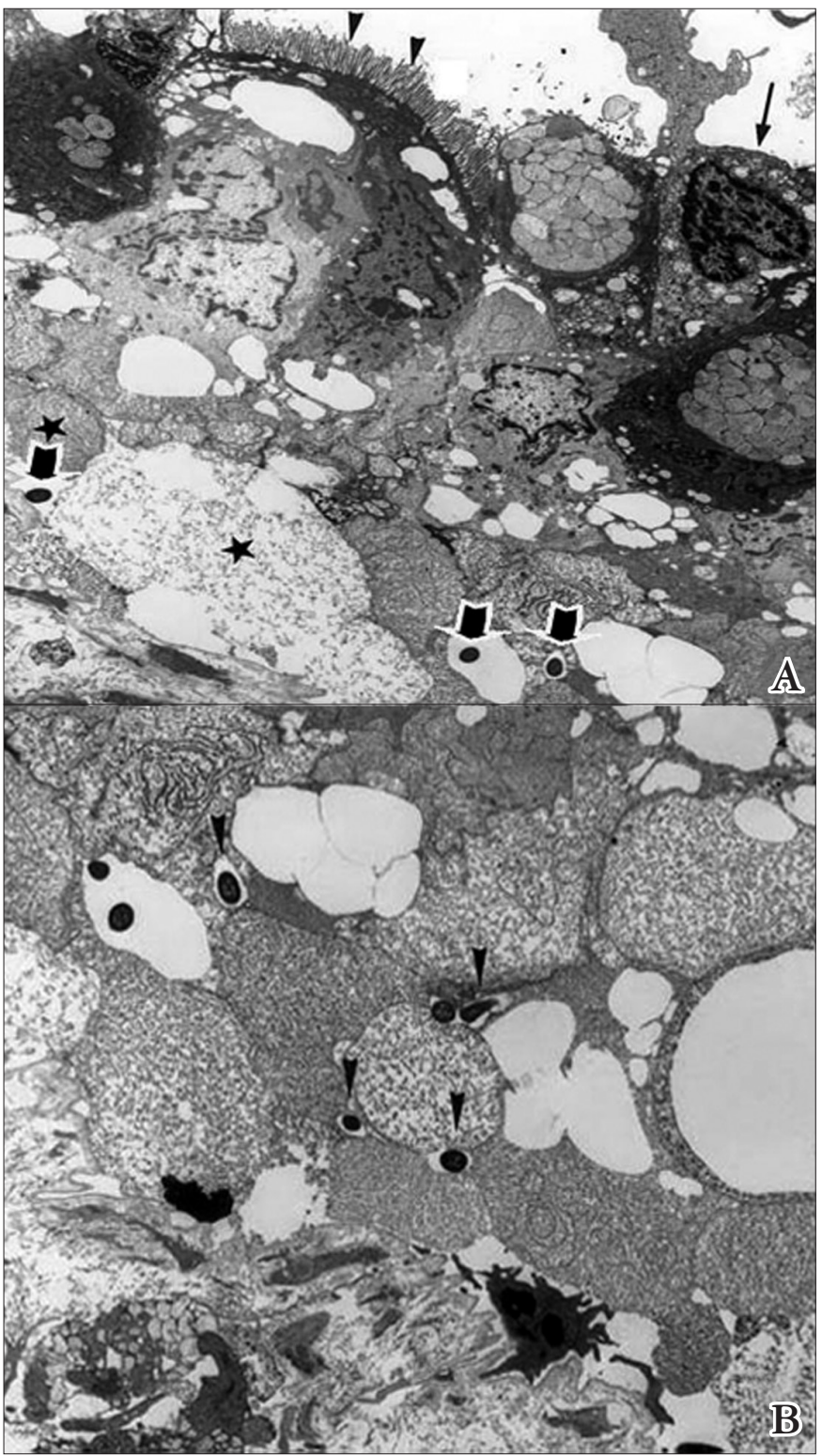

FIGURE 2. Ileal fragment infected by the prototype strain 042, showing: A - Areas of ( $)$ microvilli with patchy destruction $(\downarrow)$, epithelial detachment, vacuolization of the cytoplasm of the enterocytes $(\star)$, and internalization of some bacterial microorganisms $(\boldsymbol{\nabla})$

B - High power view of the enterocyte showing bacterial microorganisms within cytoplasmatic vacuoles (TEM: A- 2600x; B- 3900x)

All the cultures were positive and non-infected ileal fragments (negative controls) showed no apparent histologycal lesions (Figure 3).

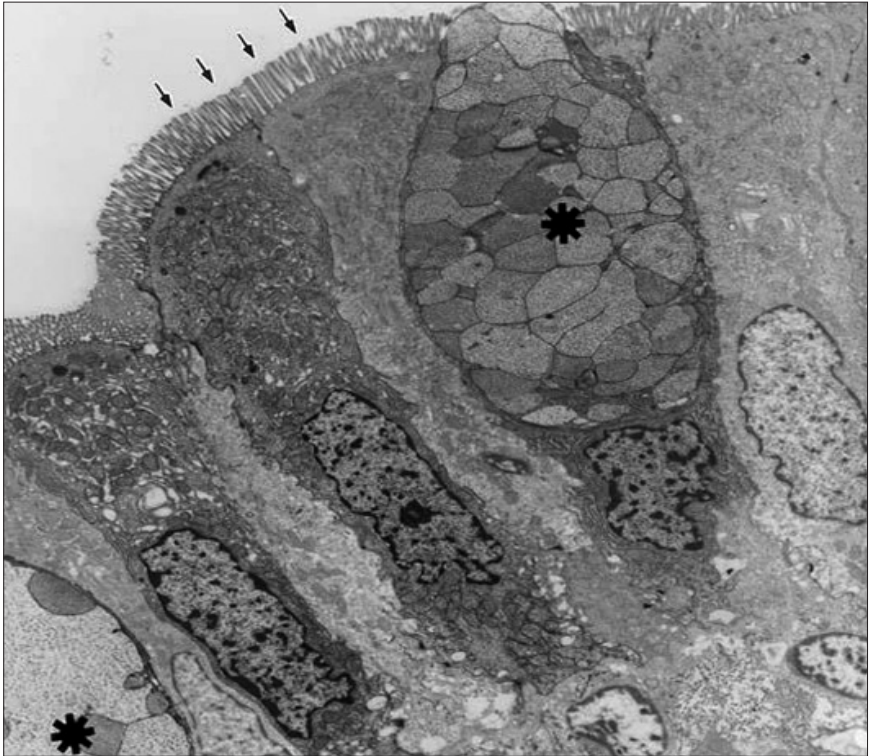

FIGURE 3. Non-infected ileal fragment (negative control) showing intact microvilli $(\downarrow)$ and preserved enterocytes. Globlet cells with mucus production is also seen $(*)$ ). (TEM: $3250 x)$

\section{Adhesion to colonic fragments}

Analysis by TEM of infected fragments showed the same alterations observed in the ileal mucosa. Bacterial aggregate was shown over the destroyed epithelium (Figure 4).

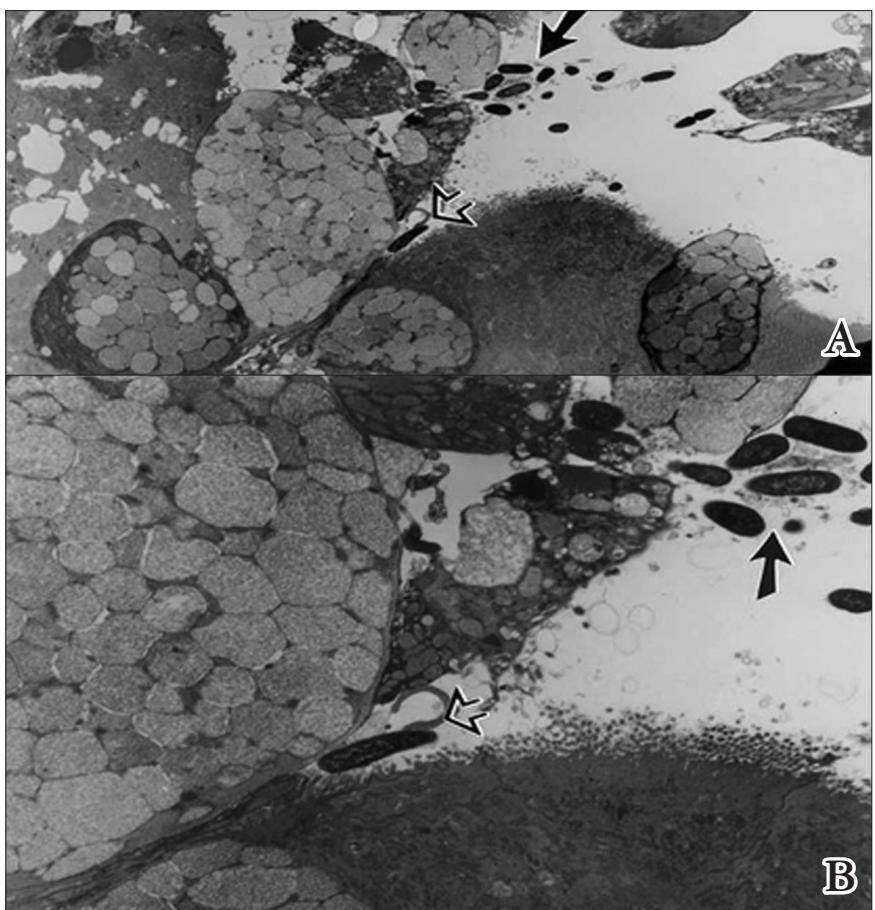

FIGURE 4. Colonic fragment infected by 171-1 EAEC strain showing: A - Bacterial aggregate over the destroyed epithelium $(\boldsymbol{})$ and between globlet cells ( $\mathbf{r}$ )

B - High power view of a microorganism that is seen between an enterocyte and a globlet cell $\left({ }_{3}\right)$. (TEM: A - 2600x; B - 6500x) 
In the colonic lumen, bacteria involved by cytoplasmatic vacuoles were seen within the cells (Figure 5A) and near of collagen fibers in the disrupted submucosa (Figure 5B). Analysis by TEM of positive controls showed bacteria near of epithelial surface, microvilli vesiculation and vacuolization of basal cytoplasm of the enterocytes (Figure 6A). Bacteria were also seen near the collagenous fibers in submucosa region (Figure 6B).

All the cultures were positive and analysis of negative controls showed intact epithelium with preserved enterocytes as well as globlet cells (Figure 7).

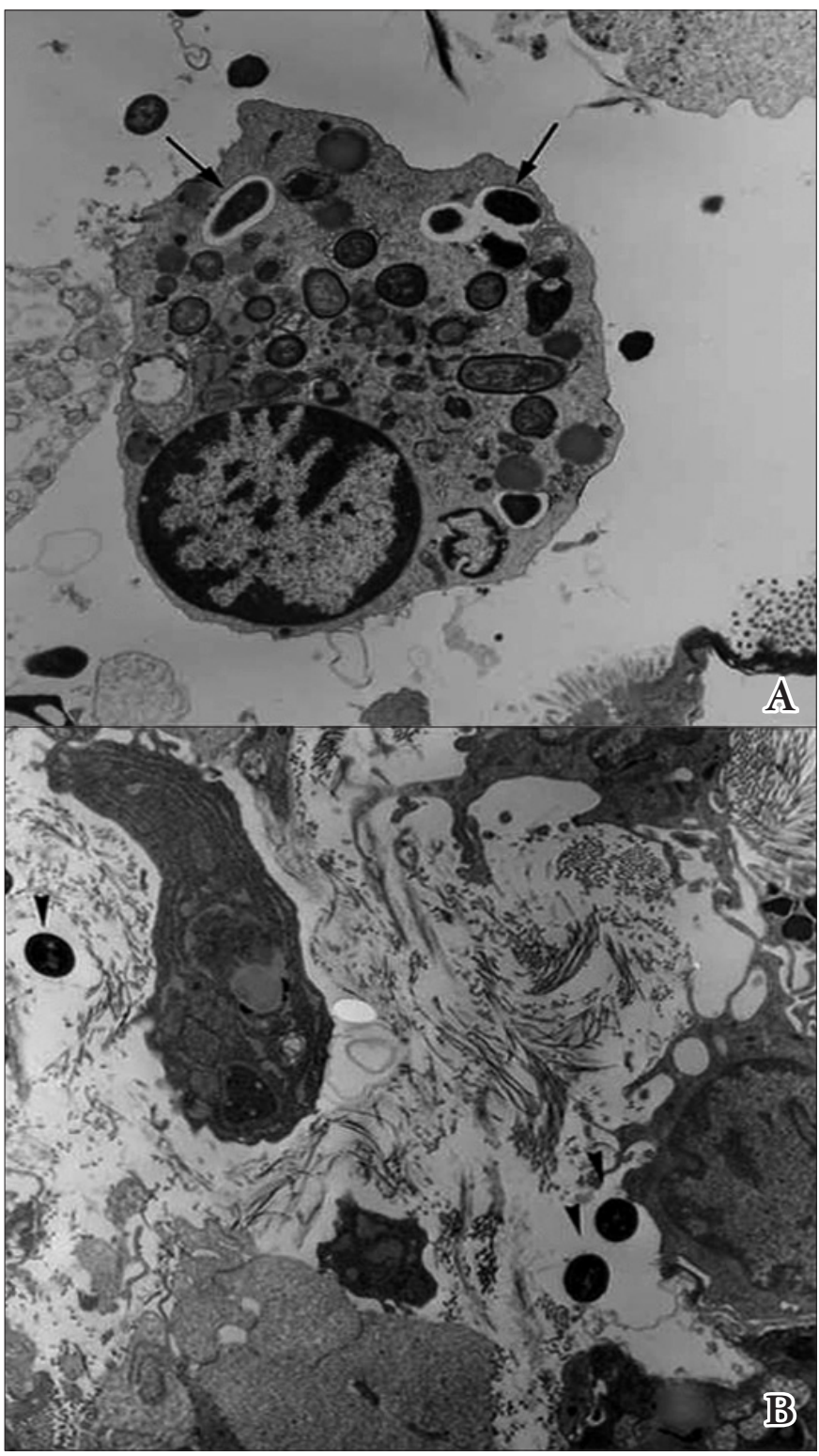

FIGURE 5. Colonic fragment infected by 171-1 EAEC strain showing: A - Several microorganisms within a detached enterocyte ( $\not$ ). (TEM: 6500x) B - Several microorganisms around collagenous fibers in the disrupted sub mucosa ( ). (TEM: 6500x)

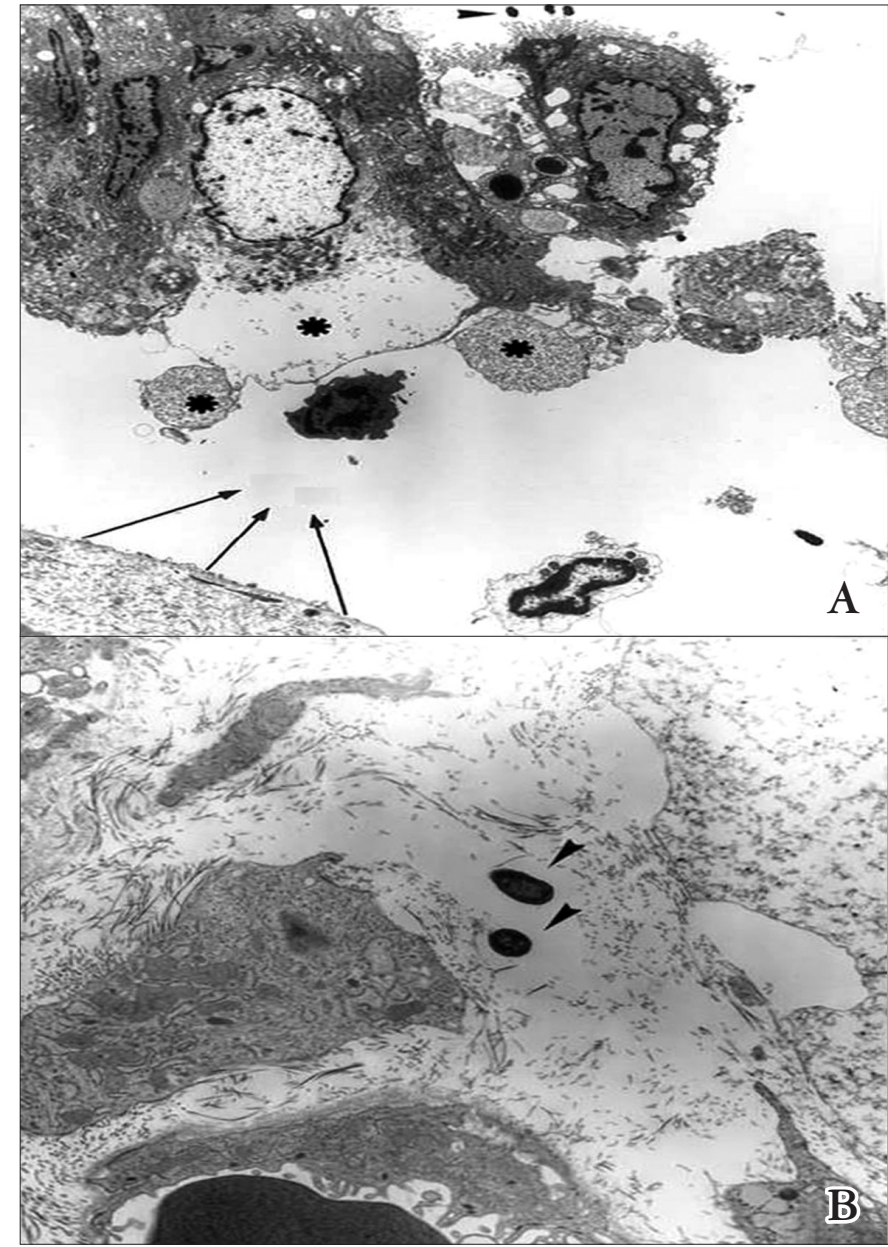

FIGURE 6. Colonic fragment infected by the prototype strain 042 showing: A - Several microorganisms over the microvilli $(\downarrow)$ and within a detached enterocyte from the basal membrane (TEM: 2600x)

$\mathrm{B}$ - Presence of the microorganisms within the mucosa around the collagenous fibers (\) (TEM: 6500x)

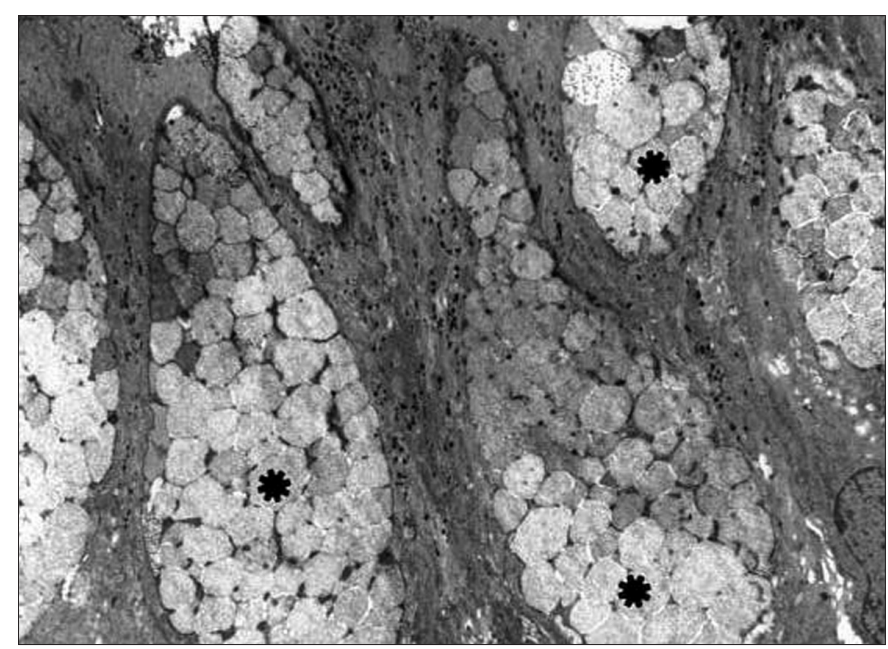

FIGURE 7. Non-infected colonic fragment (negative control) showing preserved enterocytes as well as globlet cells $(*)$. (TEM: 3250x) 


\section{DISCUSSION}

Alterations in small bowell could justify the extension of the diarrheiogenic process ${ }^{(6,16,17)}$. There are evidences that EAEC can colonize both, the small bowell and colonic mucosa, but there may be variations among different strains ${ }^{(22,23,24,45,46)}$.

The analysis of EAEC strains in several models, such as in vivo assays in animal models ${ }^{(41,42,43)}$, and in vitro organ culture with isolated enterocytes ${ }^{(38)}$ or cellular lines like T84, Caco 2, HT29, HeLa e HEp-2 ${ }^{(1,12,21,34)}$ and with intestinal fragments ${ }^{(22,23,24)}$, have shown that a plausible explanation for the persistent nature of EAEC disease involves intestinal mucosal damage. However, the mechanism of this mucosal damage is not fully understood. In spite of the fact that several studies have emphasized the association of EAEC with the colonic mucosa ${ }^{(45,46)}$, some authors have demonstrated that EAEC strains are also able to colonize the small bowel ${ }^{(23,38)}$. Human and animal studies indicate that EAEC is able to bind to jejunal, ileal and colonic epithelium ${ }^{(23,40)}$.

Several studies have demonstrated different degrees of alterations in the small bowel mucosa ${ }^{(16,17)}$ due to persistent diarrhea. Enteric pathogens commonly cause illness by damaging the cells of the villous tip or secreting toxins, which bind to the enterocytes. Recovery from a diarrheal illness occurs only when the villous epithelial cells are replaced. Thus, abnormalities that result in delayed intestinal epithelial regeneration might be expected to prolong illness ${ }^{(10)}$.

Ethical limitations have made it difficult to obtain intestinal fragments from pediatric patients for in vitro organ culture assays and some authors have used tissue from adults instead ${ }^{24,}$ 45,46). Yamamoto et al. ${ }^{(45,46)}$ found similar levels of adherence in the mucosa of children and adults. Based on these data, in the present study we have used intestinal mucosa obtained from both children and adults.

The three studied strains colonized ileal and colonic mucosa. With reference to citotoxic effects, important alterations were observed in both regions of the digestive tract. The alterations that were described in the ileal mucosa could explain the perpetuation of diarrhea. It has been hypothesized that diarrhea illness may initiate a process that contributes in continuing mucosal injury. In vivo, food malabsorption and microbial antigens may stimulate an immune response that perpetuates the damage to the mucosa ${ }^{(10)}$. On the other hand, the absence of defense mechanisms in assays performed in vitro could justify the citotoxic alterations.

The evaluated intestinal fragments showed total or partial villi destruction, vacuolization of the basal cytoplasm of the enterocytes, epithelium detachment, derangement of the tissue structure and epithelial cell extrusion. Aggregates of bacteria were seen in the intestinal lumen associated with mucus and cellular debris and within the destroyed epithelium, suggesting that an invasion process occurred secondary to tissue destruction. Some areas exhibited total epithelial destruction with absence of microvilli. These lesions confirmed the results of Vial et al. ${ }^{(43)}$ that showed in rat and rabbit intestinal loops, significant destructive lesions suggesting cytotoxic effects more severe in the distal than in the proximal small bowel.

Hicks et al. ${ }^{(23)}$ showed that EAEC strains interact with jejunal, ileal and colonic mucosa. They suggested that EAEC could provoke citotoxic changes only in colonic epithelium, although excess of cell extrusion was noted in the small bowel specimens ${ }^{(23)}$. Similar results were found by Nataro et al. ${ }^{(34)}$ with EAEC prototype strain 042. They showed that T84 cells infected by 042 strains displayed marked toxic effects prominently in areas where bacteria were adhered.

The present study showed that EAEC strains had the same type of interaction and production of mucus in both assessed regions of the digestive tract.

It is known that clinical manifestations of EAEC diarrhea vary from individual to individual, depending upon the genetic composition of the host. The distribution of interleukin-8 (IL-8) genotypes in symptomatic and asymptomatic subjects infected with EAEC has been studied. These differences may define populations with more susceptibility to EAEC infection ${ }^{(27)}$.

As described before, EAEC strains seem to have affinity with regions that are rich in mucus ${ }^{(41)}$. There was increased mucus discharge in both evaluated regions that were infected by these EAEC strains. The pathogenesis of persistent diarrhea should include alterations in the small intestinal structures where the digestive-absorptive functions take place.

Secondary internalization was observed in both regions of the digestive tract. In the ileum, the presence of bacteria seen within the cells could provoke more exposition to toxins or other substances that cause lesions and, consequently, malabsorption of nutrients and favoring the penetration of bacterial and food antigens. These antigens might stimulate an immune response that perpetuates the injury of the mucosa and consequently the persistence of diarrhea.

The available data do not allow a complete understanding of EAEC pathogenesis, yet several hypotheses have been formulated. It is supposed that the pathogenesis involves three stages: 1- adherence to the intestinal mucosa by aggregative adherence fimbriae and adherence factors; 2- production of mucus by bacteria and the host cell forming a biofilm on the surface of the enterocytes; and 3- release of toxins and elicitation of an inflammatory response, mucosal toxicity and

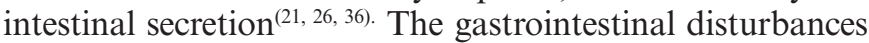
provoked by EAEC must occur by a complex host-pathogen interaction involving host genetic susceptibility, heterogeneity of virulence among EAEC strains and the amount of bacteria of the infected host.

In conclusion, this study, which examined the interaction of three EAEC strains with human intestinal tissues, has confirmed that EAEC colonizes both the small bowel and the colonic mucosa. EAEC infection may lead to damage to the absorptive epithelium of the small bowel, resulting in perpetuation of diarrhea. In the colonic mucosa the inflammatory lesions described in the present study could explain the colitis that had been reported in children suffering from EAEC infection ${ }^{(11,13,39)}$. 
Andrade JAB, Freymüller E, Fagundes-Neto U. Fisiopatologia da infecção pela Escherichia coli enteroagregativa; um modelo experimental utilizando microscopia eletrônica de transmissão. Arq Gastroenterol. 2010;47(3):306-12.

RESUMO - Contexto - A Escherichia coli enteroagregativa está associada à diarréia persistente em vários países em desenvolvimento. Procedimentos in vivo empregando modelos animais como ratos, coelhos e alças intestinais de suínos gnotobióticos, e modelos in vitro com linhas celulares, tais como: T84, Caco 2, HT29, HeLa e HEp-2 e cultura de órgão in vitro são empregados no estudo desta bactéria e de sua patogenicidade. Objetivos Neste trabalho foram avaliadas as interações de três cepas de Escherichia coli enteroagregativa usando cultura de órgão in vitro, com o objetivo de observar e comparar as alterações em diferentes regiões do intestino: mucosa ileal e mucosa colônica. Métodos - Este estudo empregou fragmentos de íleo terminal e cólon extraídos de pacientes submetidos a colonoscopia. Os fragmentos intestinais infectados in vitro foram fixados para avaliação em microscopia eletrônica de transmissão. Cada cepa bacteriana foi testada com três fragmentos intestinais de cada região. Resultados - As cepas estudadas colonizaram e provocaram efeitos citotóxicos no íleo e no cólon. Alterações na mucosa ileal, tais como: destruição parcial ou total das vilosidades, vacuolização do citoplasma basal dos enterócitos, destacamento do epitélio e desarranjo da estrutura com extrusão de células epiteliais poderiam explicar a perpetuação do processo diarréico. Agregados bacterianos foram vistos no lúmen intestinal associados a muco e restos celulares e nos espaços intercelulares do epitélio destruído sugerindo invasão bacteriana que pareceu ser secundária à destruição do tecido. Conclusão - A patogênese da diarréia persistente deve incluir alterações no intestino delgado aonde ocorrem as funções digestivo-absortivas. Na mucosa colônica as lesões inflamatórias observadas justificariam a ocorrência de colite.

DESCRITORES - Escherichia coli. Diarréia. Microscopia eletrônica de transmissão.

\section{REFERENCES}

1. Abe CM, Knutton S, Pedroso MZ, Freymüller E, Gomes TA. An aggregative Escherichia coli strain of serotype O111: H12 damages and invades cultured T84 cells and human colonic mucosa. FEMS Microbiol Letters. 2001;203:199-205.

2. Araujo JM, Tabarelli GF, Aranda KR, Fabbricotti SH, Fagundes-Neto U, Mendes $\mathrm{CM}$, Scaletsky IC. Typical enteroaggregative and atypical enteropathogenic types of Escherichia coli are the most prevalent diarrhea-associated pathotypes among Brazilian children. J Clin Microbiol. 2007;45:3396-9.

3. Bacqi AH, Sack RB, Black RE, Haider K, Hossain A, Alim AR, Yunus M, Chowdhury HR, Siddique AK. Enteropathogens associated with acute and persistent diarrhea in Bangladeshi children less than 5 years of age. J Infect Dis. 1992;166:792-6.

4. Bardhan PK, Albert MJ, Alam NH, Faruque SM, Neogi PK, Mahalanabis D. Small bowel and fecal microbiology in children suffering from persistent diarrhea in Bangladesh. J Pediatr Gastroenterol Nutr. 1998;26:9-15.

5. Baudry B, Savarino SJ, Vial P, Kaper JB, Levine MM. A sensitive and specific DNA probe to identify enteroaggregative Escherichia coli, a recently discovered diarrheal pathogen. J Infect Dis. 1990;161:1249-51.

6. Bhutta ZA, Ghishan F, Lindley K, Memon IA, Mittal S, Rhoads JM. Persistent and chronic diarrhea and malabsorption: working group report of the second World Congress of Pediatric Gastroenterology, Hepatology and Nutrition. J Pediatr Nutr. 2004;39:s711.

7. Bhutta ZA, Nelson EA, Lee WS, Tarr PI, Zablah R, Phua KB, Lindley K, Bass D, Phillips A; Persistent Diarrhea Working Group. Recent advances and evidence gaps in persistent diarrhea. J Pediatr Gastroenterol Nutr. 2008:47:260-5.

8. Binder HJ. Causes of chronic diarrhea. N Engl J Med. 2006;355:236-9.

9. Black RE, Brown KH, Becker S. Malnutrition is a determining factor in diarrheal duraton, but not incidence, among young children in a longitudinal study in rural Bangladesh. Am J Clin Nutr. 1984;39:87-94.

10. Black RE. Persistent diarrhea in children of developing countries. Pediatr Infect Dis J. 1993;12:751-61.

11. Bouckenooghe AR, Dupont HL, Jiang ZD, Adachi J, Mathewson JJ, Verenkar MP, Rodrigues S, Steffen R. Markers of enteric inflammation in enteroaggregative Escherichia coli diarrhea in travelers. Am J Trop Med Hyg. 2000;62:711-3.

12. Bouzari S, Jafari A, Azizi A, Oloomi M, Nataro JP. Short report: characterization of enteroaggregative Escherichia coli isolates from Iranian children. Am J Trop Med Hyg. 2001;65:13-4.

13. Cravioto A, Tello A, Navarro A, Ruiz J, Villafán H, Uribe F, Eslava C. Association of Escherichia coli HEp-2 adherence patterns with type and duration of diarrhoea. Lancet. 1991;337:262-4.

14. Elias WP, Uber AP, Tomita SK, Trabulsi LR, Gomes TA. Combinations of putative virulence markers in typical and variant enteroaggregative Escherichia coli strains from children with and without diarrhoea. Epidemiol Infect. 2002;129:49-55.

15. Embaye H, Batt RM, Saunders JR, Getty B, Hart CA. Interaction of enteropathogenic Escherichia coli $\mathrm{O} 111$ with rabbit intestinal mucosa in vitro. Gastroenterology. 1989;96:1079-86.
16. Fagundes-Neto U, Kallas MR, Patrício FR. Morphometric study of the small bowell mucosa in infants with diarrhea due to enteropathogenic Escherichia coli strains. Hepatogastroenterology. 1997;44:1051-6.

17. Fagundes-Neto U, De Martini-Costa SM, Pedroso MZ, Scaletsky IC. Studies of small bowel surface by scanning electron microscopy in infants with persistent diarrhea. Braz J Med Biol Res. 2000;33:1437-42.

18. Flores J, Okhuisen PC. Enteroaggregative Escherichia coli infection. Curr Opin Gastroenterol. 2009;25:8-11.

19. Gioppo NM, Elias WP Jr, Vidoto MC, Lindares RE, Saridakis HO, Gomes TA, Trabulsi LR, Pelayo JS. Prevalence of HEp-2 cell-adherent Escherichia coli and characterization of enteroaggregative $E$. coli and chain-like adherent $E$. coli isolated from children with and without diarrhoea, in Londrina, Brazil. FEMS Microbiol Lett. 2000;190:293-8.

20. Guarino A, De Marco G. Persistent diarrhoea. In: Walker A, editor. Pediatric gastrointestinal disease; pathophysiology, diagnosis, management. Philadelphia: Decker; 2004. p.180-93.

21. Harrington SM, Strauman MC, Abe CM, Nataro JP. Aggregative adherence fimbriae contribute to the inflammatory response of epithelial cells infected with enteroaggregative Escherichia coli. Cell Microbiol. 2005;7:1565-78.

22. Hicks S, Candy DC, Philips AD. Adhesion of enteroaggregative Escherichia coli to formalin-fixed intestinal and ureteric epithelia from children. J Med Microbiol. 1996;44:362-71.

23. Hicks S, Candy DC, Philips AD. Adhesion of enteroaggregative Escherichia coli to pediatric intestinal mucosa in vitro. Infect Immun. 1996;64:4751-60.

24. Hicks S, Nataro JP, Knutton S, Philips AD. 92 Cytotoxic effects of enteroaggregative Escherichia coli (Eaggec) on human intestinal mucosa in vitro. ESPGAN [abstract]. J Pediatric Gastroenterol Nutr. 1996;22:432.

25. Hochman JA, Simms C. The role of small bowel bacterial overgrowth in infantible colic. J Pediatr. 2005;147:410-1.

26. Huang D B, DuPont HL, Jiang ZD, Carlin L, Okhuysen PC. Interleukin-8 response in an intestinal HCT-8 cell line infected with enteroaggregative and enterotoxigenic Escherichia coli. Clin Diagn Lab Immunol. 2004;11:548-51.

27. Jiang ZD, Okhuisen PC, Guo DC, He R, King TM, DuPont HL, Milewicz DM Genetic susceptibility to enteroaggregative Escherichia coli diarrhea: polymorphism in the interleukin-8 promotor region. J Infect Dis. 2003;188:506-11.

28. Knutton S, Shaw RK, Bhan MK, Smith HR, McConnel MM, Cheasty T, Willians $\mathrm{PH}$, Baldwin TJ. Ability of enteroaggregative Escherichia coli strains to adhere in vitro to human intestinal mucosa. Infect Immun. 1992;60:2083-91.

29. Lima AA, Guerrant RL. Persistent diarrhea in children: epidemiology, risk factors, pathophysiology, nutritional impact and management. Epidemiol Rev. 1992;14:222-42.

30. Mathers CD, Bernard C, Iburg KM, Inoue M, Ma Fat D, Shibuya S, Stein C, Tomijima N, Xu H. Global burden of disease in 2002: data sources, methods and results. Geneva: World Health Organization; 2003 [revised 2004]. (Global Programme on Evidence for Health Policy Discussion Paper no. 54). p.45.

31. Moon JY, Park JH, Kim YB. Molecular epidemiological characteristics of virulence factors on enteroaggregative Escherichia coli. FEMS Microbiol Lett. 2005;253:215-20. 
32. Nataro JP, Kaper JB, Robins-Browne R, Prado V, Vial P, Levine MM. Patterns of adherence of diarrheagenic Escherichia coli to HEp-2 cells. Pediatr Infect Dis J. 1987;6:829-31.

33. Nataro JP, Deng Y, Cookson S, Cravioto A, Savarino SJ, Guers LD, Levine MM, Tacket CO. Heterogeneity of enteroaggregative Escherichia coli virulence demonstrated in volunteers. J Infect Dis. 1995;171:465-8

34. Nataro JP, Hicks S, Phillips AD, Vial PA, Sears CL. T84 cells in culture as a model for of enteroaggregative Escherichia coli pathogenesis. Infect Immun. 1996;64:4761-8.

35. Nataro JP, Kaper JB. Diarrheagenic Escherichia coli. Clin Microbiol Rev. 1998;11:142-201.

36. Nataro JP. Enteroaggregative Escherichia coli pathogenesis. Curr Opinion Gastroenterol. 2005;21:4-8.

37. Orlandi PP, Magalhães GF, Matos NB, Silva T, Penatti M, Nogueira PA, Silva LH. Etiology of diarrheal infections in children of Porto Velho (Rondônia Western Amazon region, Brazil). Braz J Med Biol Res. 2006;39:507-17.

38. Raj P, Bhan MK, Srivastava R, Kumar R, Bhandari N, Arora NK. Human enterocyte adhesion of enteroadherent Escherichia coli. Indian J Med Res. 1990;91:368-71.

39. Regua-Mangia AH, Gomes TA, Vieira MA, Andrade JR, Irino K, Teixeira LM Frequency and characteristics of diarrhoeagenic Escherichia coli strains isolated from children with and without diarrhoea in Rio de Janeiro, Brazil. J Infect. 2004;48:161-7.

40. Sainz T, Perez J, Fresan MC, Flores V, Jimenez L, Hernandez U, Herrera I, Eslava C. Histological alterations and immune response induced by Pet toxin during colonization with enteroaggregative Escherichia coli (EAEC) in a mouse model infection. J Microbiol. 2002;40:91-7.

41. Tickoo SK, Bham MK, Srivastava R, Dass BK, Shariff M, Saini S, Kumar R. Intestinal colonization and production of diarrhea by enteroadherent-aggregative Escherichia coli. Indian J Med Res 1992;95:278-83.

42. Tzipori S, Montanaro J, Robins-Browne RM, Vial P, Gibson R, Levine MM. Studies with enteroaggregative Escherichia coli in the gnotobiotic piglet gastroenteritis model. Infect Immun. 1992;60:5302-6.

43. Vial PA, Robins-Browne R, Lior H, Prado V, Kaper JB, Nataro JP, Maneval D, Elayed A, Levine MM. Characterization of enteroadherent-aggregative Escherichia coli, a putative agent of diarrheal disease. J Infect Dis. 1988;158:70-9.

44. Wanke CA, Cronan S, Goss C, Chadee K, Guerrant RL. Characterization of binding of Escherichia coli strains which are enteropathogens to small-bowell mucin. Infect Immun. 1990;58:794-800.

45. Yamamoto T, Endo S, Yokota T, Echeverria P. Characteristics of adherence of enteroaggregative Escherichia coli to human and animal mucosa. Infect Immun. 1991;59:3722-39

46. Yamamoto T, Koyama Y, Matsumoto, M, Sonoda E, Nakayama S, Uchimura M, Paveenkittiporn W, Tamura K, Yokota, T, Echeverria P. Localized, aggregative and diffuse adherence to HeLa cells, plastic and human small intestines by Escherichia coli isolated from patients with diarrhea. J Infect Dis. 1992;166:1295-310.

Received 23/9/2009.

Accepted 26/1/2010 